\title{
Trust and the cost of debt financing
}

\author{
Article
}

Accepted Version

Creative Commons: Attribution-Noncommercial-No Derivative Works 4.0

Meng, Y. and Yin, C. (2019) Trust and the cost of debt financing. Journal of International Financial Markets, Institutions and Money, 59. pp. 58-73. ISSN 1042-4431 doi: https://doi.org/10.1016/j.intfin.2018.11.009 Available at https://centaur.reading.ac.uk/80885/

It is advisable to refer to the publisher's version if you intend to cite from the work. See Guidance on citing.

To link to this article DOI: http://dx.doi.org/10.1016/j.intfin.2018.11.009

Publisher: Elsevier

All outputs in CentAUR are protected by Intellectual Property Rights law, including copyright law. Copyright and IPR is retained by the creators or other copyright holders. Terms and conditions for use of this material are defined in the End User Agreement.

\section{www.reading.ac.uk/centaur}

\section{CentAUR}

Central Archive at the University of Reading

Reading's research outputs online 


\section{Accepted Manuscript}

Trust and the Cost of Debt Financing

Yijun Meng, Chao Yin

PII: $\quad$ S1042-4431(18)30442-6

DOI: $\quad$ https://doi.org/10.1016/j.intfin.2018.11.009

Reference: $\quad$ INTFIN 1075

To appear in: $\quad$ Journal of International Financial Markets, Institutions \& Money

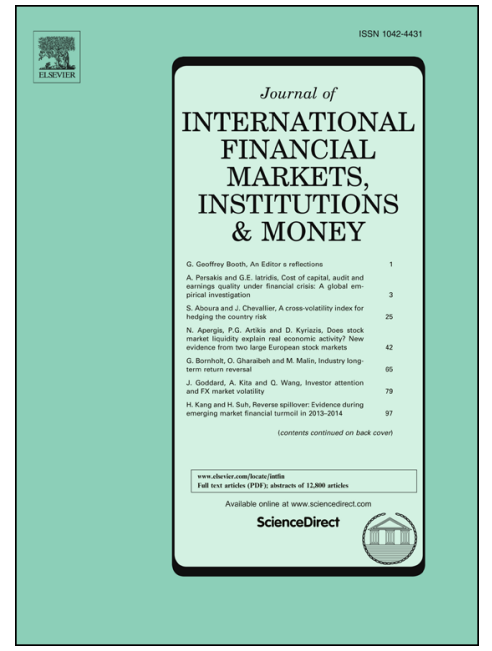

Received Date: $\quad 14$ November 2018

Accepted Date: $\quad 26$ November 2018

Please cite this article as: Y. Meng, C. Yin, Trust and the Cost of Debt Financing, Journal of International Financial Markets, Institutions \& Money (2018), doi: https://doi.org/10.1016/j.intfin.2018.11.009

This is a PDF file of an unedited manuscript that has been accepted for publication. As a service to our customers we are providing this early version of the manuscript. The manuscript will undergo copyediting, typesetting, and review of the resulting proof before it is published in its final form. Please note that during the production process errors may be discovered which could affect the content, and all legal disclaimers that apply to the journal pertain. 


\section{Trust and the Cost of Debt Financing ${ }^{\text {और }}$}

Yijun Meng ${ }^{a, *}$ and Chao Yin ${ }^{b}$

a. Shanghai University of International Business and Economics

b. ICMA Centre, Henley Business School, University of Reading

JEL Classification: F22, G34, G38

Keywords: Societal Trust, Social Capital, Bond Yield Spreads, Informal Institutions

4 This paper was presented at the 2017 Cross Country Perspectives of Finance conferences held in Chengdu, China and Chiang Mai, Thailand.

We would like to thank Zhenyu Wu (the editor) and two anonymous referees for their valuable comments in improving the quality of our research. The responsibility for any remaining errors rests with the authors.

* Corresponding author at: Shanghai University of International Business and Economics, 1900 Wenxiang Road, Songjiang District, Shanghai, 201620, P.R. China. Email address: almameng1120@ hotmail.com 


\title{
Trust and the Cost of Debt Financing
}

\begin{abstract}
This paper examines the relation between the level of trust in a country and the cost of debt. Using data on firms located in 22 countries over a 20 -year period, we quantify the country trust level and find strong evidence that firms in countries with a higher level of societal trust have lower bond yield spreads. We also find that the impact of trust on the cost of debt is more pronounced in countries with a poor governance environment and during a time of financial crisis. Overall, our results highlight the role of social capital in shaping corporate financial behavior.
\end{abstract}

JEL Classification: F22, G34, G38

Keywords: Societal Trust, Social Capital, Bond Yield Spreads, Informal Institutions 


\section{Introduction}

Capital is the resource that companies can use to generate profit and provide products to society. Both classical economics and the finance literature stress the importance of tangible assets and human capital. There is a large strand of studies that has looked at the process and efficiency of physical asset investment as well as the influence of human capital on productivity (Biddle et al., 2009; Ghaly et al., 2015; García Lara et al., 2016). A recent literature has also emerged that studies a firm's intellectual capital - their investment in research and development (R\&D). These studies not only look at firms' decision in $R \& D$ investment input (Hall, 1993; Bushee, 1998; Aghion et al., 2013), but also look at the output of innovation obtained as the result of such investment (He and Tian, 2013; Hsu et al., 2014; Tian and Wang 2014). However, compared to the extensive studies on tangible, human, and intellectual capital, another type of capital - social capital, which is equally important as a source of production - has received much less attention (Servaes and Tamayo, 2017).

Social capital contains different dimensions such as cooperative behavior, civic norms, and networking in the group, but trust is at its core (Hilary and Huang, 2015). The importance of such a notion has been expressed by different studies in different ways. For example, Arrow (1972) states that virtually every commercial transaction has within itself an element of trust, certainly any transaction conducted over a period of time", and this view is also supported by Williamson (1993). Fukuyama (1996) states that trust could enhance all institutions in a society, including business development and transactions. The central role of trust in social capital has attracted the attention of academics. Previous studies find that a higher level of trust is associated with higher economic growth (Knack and Keefer, 1997; Zak and Knack, 2001), better financial development (Guiso et al., 2004), and a higher level of stock market 
participation (Guiso et al., 2008) from a macroeconomic perspectives. However, the effect of trust on corporate financing has still been largely unexplored.

This study intends to fill such a gap by looking at the effect of trust on the cost of debt issuance. We consider three related questions to clarify the role of trust on debt financing. The first question is: how, and to what extent, could trust be a factor that influences debt cost? Based on four reasons, we propose that trust could significantly reduce the financing cost of a firm. First, trust could reduce transactions cost in a society, which could increase the efficiency of business activities and therefore build a stronger economic foundation for debt repayment (Knack and Keefer, 1997; Zak and Knack, 2001). Second, trust could encourage market participation and funding availability. The increase in funding supply would lead to lower funding costs (Guiso et al, 2008a, 2008b; Duarte et al., 2012; Bottazzi et al., 2016). Third, trust among people improves the information flow of the market and therefore reduces the monitoring cost of creditors (Pevzner et al., 2015). Fourth, trust could serve as a way to mitigate the agency problem which could also lower the cost of debt (Chami and Fullenkamp, 2002; Dudley and Zhang, 2016).

We look at the issuance yield of Yankee Bonds as our proxy for debt financing cost. Following earlier studies (Dudley and Zhang, 2016; Guiso et al., 2008a, 2008b, etc.), we measure trust at a country level based on the citizens' average response to the question in the World Values Survey (WVS) and the European Value Survey (EVS): "Generally speaking, would you say that most people can be trusted or you need to be very careful in dealing with people?"1 By examining 6,098 issues from 24 countries from 1996 to 2015, we find firms with a higher level of societal trust have a lower cost for borrowing debt. One standard

1 The data of the World Value Survey (WVS) is from the official WVS website: http://www.worldvaluessurvey.org/wvs.jsp; and the data from the European Value Survey (EVS) is from http://www.europeanvaluesstudy.eu/. 
deviation increase in trust would lead to a $0.77 \%$ lower yield when firms are issuing bonds. This number is both statistically and economically significant, and confirms our hypothesis that the level of societal trust among people has a real impact on firms' financing cost.

The second question to be answered is: how does trust interact with other country governance mechanisms in reducing agency cost? Both formal and informal institutions play important roles in economic growth. However, the relative importance and interaction of both mechanisms in determining financing cost is unknown. On the one hand, formal institution could provide a channel for trust to be maintained and distrust to be punished. As a result, when formal institution is stronger, the effect of trust on cost of debt could be more salient. On the other hand, if trust as an informal institutional has independent value and could manifest itself through other channels, it could be a substitute to the formal institution. As a result, we could observe weaker effect of trust on cost of debt when the formal institution is stronger. Our analysis confirms the second argument. Moreover, we find that among six dimensions of country governance, the effect of trust in reducing the cost of debt is related to government effectiveness, control of corruption, political stability, and voice and accountability, but less correlated with regulatory quality and the rule of law index.

The last question to be looked at concerns the effect of trust on financing cost during the financial crisis. At a time when credit becomes scarce, and resources and collateral become increasingly important in obtaining funding, will trust between people be helpful in alleviating panic, smooth credit transactions and therefore have an impact on the real economy? We find that a higher level of trust among people could significantly lower the impact of a financial crisis in increasing financing cost. These findings provide additional evidence on the effect of trust on the real economy. 
We conduct a battery of methodologies to examine above questions, including ordinary least squares (OLS) regression, Tobit regression, and higher order fixed effects. Additionally, we also employ different methods to rule out the possibilities of reverse causality, multicollinearity issues, and so on, by performing a variety of robustness checks. Our results are robust and valid after conducting these robustness checks.

Our paper contributes to the literature in several ways. First, by investigating the relationship between trust and the cost of debt, we can quantify the valuation of market participants on social capital and show that social capital will be an important resource of the firm, as is not only being acknowledged by academics, but also by market participants. Second, we contribute to the governance literature by providing evidence that trust can serve as a supplement to the traditional channel of corporate monitoring. We also contribute to the literature investigating the financing of the firm during a financial crisis by providing the evidence that social capital in stabilizing the shock created by the crisis.

The structure of the paper is as follows. Section 2 introduces background and formulates hypotheses. Section 3 introduces the sample construction, describes the variables, exhibits the model specification, and presents summary statistics. Section 4 reports the regression results. Section 5 presents a variety of robustness checks. Section 6 provides further discussions. Section 7 offers some concluding remarks.

\section{Theoretical Background and Hypotheses Design}

Governance institutions can be divided into formal and informal ones, depending on their nature and enforcement. Helmke and Levitsky (2004) define informal institution as "socially 
shared rules, usually unwritten that are created, communicated and enforced outside of officially sanctioned channels". Informal institutions can shape the way that people look at the world (Chui et al., 2002), determine the reaction of people to the events occurring in the world (Witt and Redding, 2009), and influence the way people interact with each other (Zilber, 2006). They are also the underlying base that the formal institutions of a society are based on (Holmes et al., 2011). There is a large strand of literature confirming the crucial role of informal institutions in the economy. ${ }^{2}$

As a crucial type of social capital, societal trust is an informal institution in a country. The level of trust could be an important factor that influences the financing cost of firms. There are two types of trust in the discussion of the cost of capital. The first one is personal trust, which is the set of beliefs of a certain firm or individual. The second notion is societal trust, which could be viewed as a set of beliefs of a group of firms or individuals (Dudley and Zhang, 2016). While both types of trust are important in the financial market, this paper mainly focuses on societal trust. The main reason for this choice is that personal trust can only be established after repeated interaction. It relies on the long-term relationship between two parties. When a firm is seeking international debt financing, the investors and firms are likely to be separated both geographically and culturally, therefore their beliefs about each other would be more likely to be based on societal instead of personal trust. Therefore, compared to personal trust, societal trust is more relevant in our study.

\footnotetext{
${ }^{2}$ For example: Fukuyama, (1995), Guiso et al. (2009), Guiso et al., (2004), Duarte et al. (2012) Bottazzi et al. (2016b), Ahern et al. (2015).
} 
The asymmetry of information (Myers and Majluf, 1984) makes debt holders concerned about managers' expropriation. Specifically, responding to managers' opportunistic behavior and potential wealth expropriation, debt holders will require a higher payback of debt from firms if they anticipate that managers are less trustworthy. On the contrary, in a more trustworthy society, debt holders face lower market uncertainty and require a lower price for their debt investment in the firm. In addition, trust changes the level of risk aversion. For instance, in a more trustworthy country, investors are willing to bear higher risk and demand lower premiums. Trust also changes transaction and monitoring costs. With a higher level of trust, investors may not need to spend a significant amount of resources to investigate the firm before debt issuance and/or monitor the firm's daily operations after investment, which could lead to a lower cost of debt. Finally, trust reduces business cost and increases operational efficiency. Overall, trust in a society may lead to a reduction of business cost. For example, in a highly mutual-trust country, supermarkets may not need to use many anti-theft devices, which could reduce their operational cost and lead to lower financing cost. These agreements imply that trust should have a negative direct effect on the cost of debt. On this basis, we develop the following hypothesis:

H1: Firms in a more trustworthy society have a lower cost of debt financing: bond spreads.

The informal institution is important to a country. However, the effect of it on the society is neither independent nor static. To get a comprehensive understanding on how trust could 
influence financing cost, we have to fit our discussion to the general background of a country's governance and link it to the economic condition. For this purpose, this paper also looks at how trust interacts with the formal institution to determine the cost of debt and how this effect varies with the condition of the financial market.

Existing studies find interactions between formal and informal institution in determining the economic outcome ( Holmes et al., 2011; Pevzner et al., 2015). However, the interaction of trust and formal institutions in influencing the cost of debt is still unknown. Previous studies find that formal institutions in a country are ultimately the outcome of informal institutions (Reed, 1996; Redding, 2005; Jackson and Deeg, 2008). If the level of societal trust has been incorporated into the design and enforcement of formal institutions, such institutions would be the main channel through which trust could effectively influence the cost of debt. This argument implies a complementary relation between trust and formal institutions. In other words, when the formal institution is more effective, the impact of trust on the cost of debt is more prominent. On the other hand, formal and informal institutions have different values, as formal institutions are not perfect (Helmke and Levitsky, 2004). If the effect of trust on debt financing cost could manifest itself through different channels, informal institutions could be more important in business activity when the formal institution was weak. If so, we could therefore observe a substitution effect of trust on the cost of debt (Guiso et al., 2004). These opposing arguments imply that the contingent effect of trust on the cost of debt is unknown; therefore, we propose the following hypotheses: 
H2a: The effect of trust on the cost of debt is more pronounced in countries with weaker governance quality.

$\mathrm{H} 2 \mathrm{~b}$ : The effect of trust on the cost of debt is more pronounced in countries with stronger governance quality.

Institutively, the financial crisis brings instability to current financial developments. Stiglitz (2008) argues that "The present financial crisis springs from a catastrophic collapse in confidence. Financial markets hinge on trust, and that trust has eroded." ${ }^{3}$ Lins et al. (2017) also argue that trust is an important "asset" of a society, and investment on it would pay off when trustworthiness is more valuable, such as in a period of financial crisis. These studies stress the important role of trust during financial instability. During a financial crisis, investors demand higher risk premiums on debt to provide financing. In this case, a higher level of trust in a society could perform a more important role in reducing financing cost.

Hence, the following hypothesis is proposed:

H3: The effect of trust on the cost of debt is more pronounced during a financial crisis.

\section{Methodology and Descriptive Statistics}

\footnotetext{
${ }^{3}$ We don't think that this statement implies that a financial crisis would weaken the trust at a societal level. First of all, our data did not support this argument as we do not find a significant change in the level of trust after the financial crisis. Second, trust is widely connected to the culture, history, and formal institutions of a society. Compared to the broad context in which the trust is embedded, financial markets play only a very small part in the determinants and are unlikely to play major role in the variation of societal trust.
} 


\subsection{Construction of the Sample}

Following Boubakri and Ghouma (2010) and Qi et al. (2011), we start our sample with all bonds issued in the US market by foreign investors (Yankee Bonds) in the DataStream database from 1996 to 2015. We concentrate our analysis on the Yankee market to make sure that the variations in the financing cost of the firm originates from differences in the firms instead of differences in the investors. ${ }^{4}$

We then merge our sample with Compustat database to obtain the firm-level accounting variables. We consider all firms that have complete information on both bond- and firm-level information. Finally, we merge the data with country-level variables such as trust, governance environment, and country-level controls, which are GDP growth, inflation rate, and domestic bond market size. We obtain a final sample with 6,098 bond issues. Table 1 reports the distribution and the description of our sample. Most bonds were issued after 2006, especially during 2008-2012, weighting about $67 \%$ of total issues. Table 1 also shows that most issues of Yankee Bonds come from the UK, and then Germany.

3.2. Variables and Data Source

Cost of Debt Measures

4 A detailed discussion on the Yankee market can be found in Miller and Puthenpurackal (2002). 
Following the literature, we use the bond issuance yield as our proxy for the cost of debt financing (Boubakri and Ghouma, 2010; Oikonomou et al., 2014). We define the bond spread (Spread) as the yield to maturity of a bond at issuance minus the yield to maturity of a US Treasury Bond of a similar maturity. We obtain the yield to maturity data from the Thomson Reuters DataStream.

Trust Measure

Our measure of societal trust comes from the official websites of WVS and EVS. These two surveys, which began in 1981 and are updated every 4-5 years, provide rigorous and high-quality research designs to global networks of social scientists studying changing values and their impact on social and political life. The WVS consists of nationally representative surveys conducted in almost 100 countries which contain almost $90 \%$ of the world's population, and the EVS covers 47 European countries. Moreover the WVS and EVS are the major academic studies covering the full range of global variation, from poor to rich countries, in all of the world's major cultural zones, and hence are appropriate and reliable sources to quantify societal trust. The key variable Trust is measured as the standardized score capturing the level of societal trust following the survey question from WVS and EVS:

"Generally speaking, would you say that most people can be trusted or you need to be very carefully in dealing with people?" 
The value of Trust is defined as the ratio of people who responded to the survey with the answer "most people can be trusted" over the total people who carried out the survey. We fill the missing values following the most recent surveys for years between two adjacent surveys.

Country Governance Indicator

Following Kaufmann et al. (2009), our Country governance indicator is taken from the Worldwide Governance Indicator available from the World Bank, that captures the level of investor protection. It consists of six components: government effectiveness (GE), regulatory quality (RQ), control of corruption (CC), political stability (PS), rule of law (RL), and voice and accountability (VA). More details of these six dimensions are presented in Appendix A. We calculate the aggregate value of these six dimensions as our Country governance indicator (CGIndicator).

\section{Control Variables}

For control variables, following earlier studies such as Boubakri and Ghoum (2010) and Oikonomou et al. (2014), we include country-, firm-, and bond-level characteristics. For country-level controls, we include GDP growth (GDPgrowth), Inflation rate to reflect the country's macroeconomic conditions, and the ratio of total debt issued over GDP (DebtMkt) 
to reflect each country's debt market size. The country-level variables can be found in World Bank public data. For firm-level controls, we have firm size Asset (the natural logarithm of the firm's total assets), return on investments (ROI) that indicates firm performance, Leverage that captures the ratio of total debt to total assets, and firms' operational risk that is measured as the standard deviation of return on assets (ROA) for year-4 to year; more information will be provided in Appendix A. The firm-level variables are from Compustat. For bond-level controls, we employ the natural logarithm of years to maturity (Maturity), the natural logarithm of the total amount of bond issue as bond issue size (Lisize). The bond-level controls are available from DataStream.

\subsection{Model Specification}

As discussed in detail in Section 3.1, the whole sample covers 1996-2015, which collects 6,098 different Yankee Bond issuances issued by different firms during this period. Hence, we will recognize each issuance as an observation to obtain a cross-sectional dataset and conduct the OLS regression. In order to control for any endogeneity issues arising from the omitted variables that are correlated with the included variables, fixed effects will be used. The fixed effects formulation implies that differences across groups can be captured in differences in the constant term. In sample period, some firms may only issue bonds once, industry fixed effects rather firm fixed effects may therefore be more appropriate in baseline models as the bond spread and firm fixed effect will be perfectly correlated for these firms. 
However, we will also present a firm fixed effects model and higher order fixed effects as robustness checks. In short, we will estimate the following models:

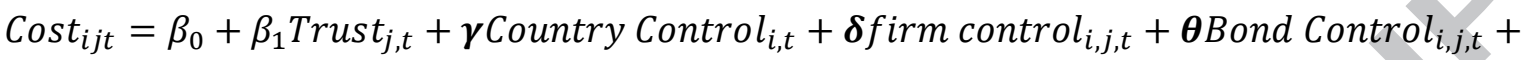
Fixed Effects $+\epsilon_{i j t}$

$\operatorname{Cost}_{i j t}=$

$\beta_{0}+\beta_{1}$ Trust $_{j, t}+\beta_{2}$ CG indicator $+\beta_{3}$ Trust $\times C G$ Indicatior $+\gamma{\text { Country } \text { Control }_{i, t}+}_{+}$ $\boldsymbol{\delta}$ firm $_{\text {control }}^{i, j, t}+\boldsymbol{\theta}$ Bond Control $_{i, j, t}+$ Fixed Effects $+\epsilon_{i j t}$

Cost $_{i j t}=\beta_{0}+\beta_{1}$ Trust $_{j, t}+\beta_{2}$ Financial Crisis $+\beta_{3}$ Trust $\times$ Financial Crisis +

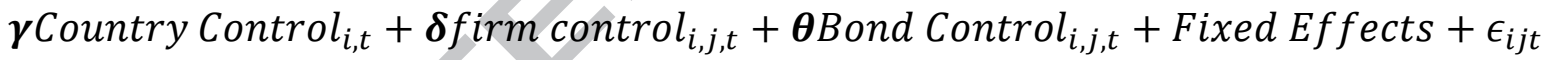

where $i$ indexes a firm, $j$ indexes a country, and $t$ indexes a year; Cost of Debt denotes bond spread; Trust $_{\mathrm{jt}}$ is the response to WVS for country $j$ in year $t$; and CGIndicator je $_{\text {in }}$ is the aggregate World Bank Worldwide Governance Indicator. Financial Crisis is a dummy variable equal to one if the world has suffered a financial crisis (2007-2009), and zero otherwise. Each of these three models tests hypotheses $\mathrm{H} 1-\mathrm{H} 3$, respectively.

\subsection{Descriptive Statistics}


Panel A of Table 2 reports the average value of trust and the six dimensions of country governance by each country from 1996 to 2015. Panel B shows the average of other country-level variables, including the aggregate level of CGindicator, the mean value of country-level controls in the same period. We also report both mean and median bond spread for 6,098 bond issues across different countries in Panel B.

As shown in Panel A, the trust level varies across different countries. Brazil (0.07) and Malaysia (0.09) are among the countries with the lowest trust level, while the Scandinavian countries, such as Demark, Norway, and Sweden have the highest level of trust, approximately 0.7 . There is also a variation in the level of country governance environment. Argentina, Brazil, India, Malaysia, and Mexico show one or more negative values of the country governance sub-components, and the Scandinavian countries still exhibit the highest score of governance indicator.

Looking at Panel B, the first column is the sum of the six governance dimensions reported in Panel A. We can find on average that the less developed countries have a weaker governance environment compared to the more developed countries. For instance, India has the lowest governance score (-1.51) and Finland has the highest (11.24).

For the country-level controls, India has the highest ratio (6.89\%) of GDP growth on average; Japan and Singapore have quite high levels of inflation, reaching $2.68 \%$ and $4.37 \%$, respectively. Belgium, Japan, and Greece are highly leveraged countries, with a ratio of total debt to GDP higher than $100 \%$.

Turning to the bond spread, we find that the variation of spread also exists in different 
countries. Canada, the UK, Norway, and Switzerland have the highest bond yields, with the spread around $10 \%$, while the countries with the lowest spread, such as India and Singapore, only issue bonds at a yield of $1 \%$ higher than the benchmark Treasury Bill.

Table 3 reports the descriptive statistics of each variable (Panel A) and Pearson Correlation (Panel B). To mitigate the extreme outliers, we winsorize firm- and bond-level variables (including the bond spread) by $1 \%$ level at both tails. Panel A shows that the mean value of Spread is $9.08 \%$, with the standard deviation as $5.1 \%$, and it varies from 0 to $19.83 \%$. Panel B reveals an important finding, that trust is negatively (-0.079) and significantly (at the $1 \%$ significance level) correlated to bond spread, which is consistent with H1. The correlations between trust and country governance indicators as well as GDP growth are significantly positive, and those correlations with the inflation rate and domestic debt market size are significantly negative. Panel B also reports that the correlation between Trust and CGindicator is just around 0.5 , more accurately 0.544 , and this figure reduces our concerns about multicollinearity between these two variables.

\section{Econometric Estimation}

\subsection{Trust and the Cost of Debt}

This section investigates the relation between trust and the cost of debt financing by using panel regressions that control for a variety of fixed effects. One possible concern is that trust may be highly correlated to the country governance indicators, though as reported in Panel B of Table 3 this is not a major concern. In order to largely free us from this issue, we conduct a multivariate regression clustered at a firm level and include the above variables as controls in addition to the primary measure of trust. We also control for unobserved industry variations 
by adding industry fixed effects at the 2 digit SIC level and control for unobserved time-invariant effects by employing year fixed effects. Table 4 reports our baseline results, with the odd columns controlling for the country fixed effects and Columns the even columns without country effects.

Columns (1) and (2) examine the full sample. Looking at Column (1), that controls for country effects, trust is significantly and negatively related to bond spread, which confirms H1. With a one standard deviation increase in trust, the firm could issue debt at a $0.77 \%$ low yield $(-9.835 \times 0.078)$. This effect is both statistically and economically significant. Column (2) reports a similar finding in a regression without country effects.

To avoid the concern that our result is mainly driven by certain issuers which dominate Yankee Bond issuance, we exclude bond issuance by the most frequent issuers as a robustness check and only include firms with fewer than 50 (Columns (3)-(4)) and fewer than 20 (Columns (5)-(6)) issues per year in the analysis. Both sub-samples are also examined with and without country fixed effects, and all of them report similar results to those reported in Columns (1) and (2), implying that the findings obtained by the baseline model are robust and solid.

The results reported in Table 4 confirm our first hypothesis that, as representing social capital, a country's societal trust does lower firms' cost to borrow debt, and that this impact is both statistically and economically significant.

\subsection{Country Governance, Trust, and the Cost of Debt}

In this section, we test $\mathrm{H} 2$ and explore how the effect of trust varies between firms with 
different country governance environments by interacting the country governance indicator (CGindicator) with Trust, and including both CGindicator and the interaction term of Trust ${ }^{*}$ CGindicator into the model. As shown in Column (1) of Table 5, the effect of trust is significantly different in countries with a better and a poor governance environment. The interaction term is positive and significant at the $1 \%$ level, which implies that trust has a more pronounced effect on the cost of debt in poor governance countries, and hence the results confirm $\mathrm{H} 2 \mathrm{a}$ that the effect of trust on the cost of debt is more pronounced in countries with weak governance quality.

We next explore if the country governance indicator is driven by one particular dimension of governance indicator by adding each sub-component in the model, and report the results in Columns (2)-(7) of Table 5. To avoid any multicollinearity issue, we exclude the variable CGIndicator and only include each of six dimensions along with its interaction with trust in each regression. As shown in Columns (2)-(7), Trust still stays significantly negative (5\% significance level and higher) for four dimensions except for Regulatory Quality and Rule of Law. In addition, the interaction effect seems not to be driven by an individual effect of a sub-component of governance indicators. In sum, these findings confirm $\mathrm{H} 2$ that the country governance environment moderates trust's impact on corporate debt financing - that is, the negative effect of trust on bond spread is stronger in weak governance countries. These results imply that as a core notion of informal institution, trust has a substitution effect with country governance environment, which is generally known as the formal institution. When the formation institutions are weak, the informal institutions could be more important in influencing business activities.

\subsection{The Cost of Debt during a Financial Crisis}


In this section, we test $\mathrm{H} 3$ and investigate whether trust will influence corporate financing cost during a financial crisis. Intuitively, firms have to offer higher yields to attract investors during a financial crisis, and the firms located in low-trust countries may have to provide more returns to debt holders. Based on this basis, we create a dummy variable FCrisis that is equal to one if firms were suffering the most recent financial crisis. Specifically, FCrisis is defined as one if the year is between 2007 and 2009, and zero otherwise. We interact it with Trust and add FCrisis and the interaction term into the model. Table 6 presents the results with and without country effects in Columns (1) and (2), respectively, and they show similar findings except that the interaction term in Column (2) loses significance. The only difference between two columns is whether the regression model adds country fixed effects; as this is a cross-country study, estimating results with country effects reported in Column (1) might be more meaningful. From Table 6, we can find that the coefficient of FCrisis is statistically significant and positive, suggesting that firms have to pay higher returns on debt borrowing during a financial crisis. The negative correlation of the interaction term implies that trust plays a more pivotal role during a financial crisis. All in all, these results confirm $\mathrm{H} 3$ that during a financial crisis, the effect of trust on debt cost is more pronounced, whereas trust plays a role to alleviate panics arising from financial distress among investors.

\section{Robustness Checks}

In this section, we conduct several robustness checks to see if the results obtained above still hold, and present the results in Table 7. To conserve space, we do not report control variables in Table 7 though we have included all controls when running regressions.

\subsection{Tobit Model}


First, as all the values of corporate bond spread are larger than zero, we adopt the Tobit regression which was proposed by James Tobin (Tobin, 1958). Unlike OLS, the Tobit regression describes the relationship between independent variables and a non-negative dependent variable, and hence may provide more robust and solid results compared to OLS in this study. Panel A of Table 7 reports the results by re-estimating $\mathrm{H} 1-\mathrm{H} 3$, for all three regressions; we control for year, industry, and country fixed effects and cluster the standard deviation at the firm level. Column (1) re-examines H1, and reports that with a one unit increase in trust, the bond spread yield can be lowered by $10.417 \%$, and this finding is significant at the 5\% level. Column (2) re-examines H2, which confirms that trust's impact on a lower bond spread is more pronounced in countries with a weak governance environment, and all coefficients are significant at the 5\% level and higher. Column (3) re-examines $\mathrm{H} 3$; though the direct impact of trust on bond spread loses significance here, the interaction term of trust and financial crisis is still significant, suggesting that during a financial crisis, trust could alleviate investors' panic and smooth the financial market.

\subsection{Reverse Causality}

Second, one common endogeneity concern arising is reverse causality - that the independent variable is actually the cause of change in the dependent variable. Though we believe that this concern does not apply to our study, more specifically, as it is highly unlikely the trust between people in a country is the result of financing cost, we will still re-examine H1-H3 by employing the lagged value of trust and country governance indicator in order to rule out the possibility of reverse causality. 
Panel B of Table 7 reports the regression results estimated from $\mathrm{H} 1-\mathrm{H} 3$, respectively. As shown, we find that the results are consistent with those reported in Tables $4-6$, that the lagged value of trust has a significantly negative impact on the cost of debt financing, and that this impact is more pronounced in countries with weak governance quality and during a financial crisis.

\subsection{A Variety of Fixed Effects}

Panel $\mathrm{C}$ of Table 7 reports the estimations of another four robustness checks. Another potential endogeneity, which could raise concerns about our argument, is omitted variable bias. The bond spread depends on various factors so that it is practically impossible to fully control for all of them in an empirical study. Our main analysis already includes the year, country, and industry fixed effects; therefore, time-invariant and cross-sectional-invariant factors are less likely to cause a problem. To further alleviate such concern, we employ firm fixed effects to remove firm specific characteristics. To conserve space, we only report the results by re-estimating $\mathrm{H} 1$, which are presented in Column (1) of Panel $\mathrm{C}$. We find that both the signs and significance of coefficients are consistent with those reported in Table 4.

Additionally, we also adopt the identification from Gormley and Matsa (2014) by employing a high order fixed effects' specification in our tests. The results of re-estimating $\mathrm{H} 1$ are reported in Column (2) of Table Panel C, which includes country-level fixed effects and the double fixed effects of Year $\times$ SIC Industry Code. Industry is a time-invariant effect, so when we multiply it with Year then the interaction term varies with time and could eliminate unobserved firm and industry-specific characteristics which vary across time. The results are also consistent with those reported in Table 4. 
5.4 Multicollinearity Issue

As reported in Table 3, the correlation between Trust and CGindicator is 0.544 , which it may not exist multicollineariy problem between these two variables. Additionally, we also separate all 6,098 observations into four groups and comparing the value of CGindicator and Trust to the sample median. We find that there are 3,541 observations in group of high trust weak formal institution ( $58 \%$ of all observations) and 1,300 observations in group of low trust and strong institution (21\% of all observations). As there are enough observations in these two groups, multicollinearity problem is not a significant issue. ${ }^{5}$ However, to further rule out this possibility, we re-run $\mathrm{H} 1$ by only including the variable Trust and find that the results reported in Column (3) of Table Panel C are similar to those obtained by having both Trust and CGindicator, which implies that multicollinearity seems not to be a significant issue.

5.5 More Control Variables

For the bond-level control variables, we have included the bond issue size and maturity followed earlier studies (Boubakri and Ghouma, 2010; Oikonomou et al., 2014). Bond credit rating and covenants are associated with bond risks, investor confidence, etc., and hence may be correlated to the cost of debt. Due to data limitation, only debt ratings can be examined. Following Boubakri and Ghouma (2010), we convert Standard \& Poor's bond ratings to a seven-grade rating scale, with a higher figure reflecting a higher rating of corporate bond. We present the credit rating transformations in Appendix B. Column (4) of Panel C reports the results by adding credit ratings as a control variable to re-examine $\mathrm{H} 1$. As shown, credit

\footnotetext{
${ }^{5}$ We thank an anonymous referee to suggest us to do this test to mitigate the multicollinearity issue.
} 
ratings have a significantly negative impact on the cost of debt, more specifically; a higher rating of bond rating may improve investors' confidence and hence reduce the cost of debt issuance. Moreover, the coefficient of Trust is in line with that without credit ratings.

In short, this section conducts a variety of robustness checks and confirms that our results obtained from baseline models are solid and robust.

\section{Further discussions}

6.1. Why specific country governance dimensions are useful

In Table 5, we report the results by estimating six country governance indexes, and find that the effect of trust in reducing the cost of debt is related to government effectiveness, control of corruption, political stability, and voice and accountability, but less correlated with regulatory quality and the rule of law.

Bris and Cabolis (2008), Dudley and Zhang (2016) and Martynova and Renneboog (2008) propose that formal institution can lower transaction costs, and hence in our study four dimensions of country governance quality are observed to lower the cost of debt. However, Gilardi (2010) points out it has proven very difficult to differentiate between possible causal mechanisms given the existing state of theory and available econometric techniques in practice.

According to Kaufmann et al. (2009), regulatory quality captures the ability of the government to formulate and implement sound policies and regulations that permit and promote private sector development. However, Kaufmann and Kraay (2008) and Kaufmann 
et al. (2009) also point out there are often gaps between de jure rules and their de facto implementation in the real world, and the correlation between the two is weak in some countries. A higher index of regulatory quality may imply both high levels of rule formulation and implementation, but it also can be a combination of a high level of rule formulation but a low level of rule implementation, which are difficult to differentiate. Therefore, this index may not have a significant impact on reducing cost of debt. Another index rule of law captures perceptions of the extent to which individuals and agents have confidence in and abide by the society. A higher index is expected to lower the cost of debt; however, we do not observe significant findings. Kaufmann and Kraay (2008) do admit that governance indicators may also contain unobserved broad dimensions of governance, and hence it is possible that some unobserved factors may explain the insignificant findings, which can be explored in future. Empirically, Dudley and Zhang (2016) also find that higher levels of government effectiveness, as well as voice and accountability, will lower agency problems and reduce the corporate cost to capital markets, though they also find that regulatory quality matters in their study. These questions also can be explored further in future studies.

\subsection{Limitation of the study and suggestions for future research}

This paper is by no means perfect. We admit that some limitations in this study and there are still some related questions left unanswered. First, this paper only considers debt as a financing tool, while the cost of equity and associated overall cost of capital are not investigated. A related question is that the change of debt financing cost could lead to a change in the capital structure of the firm. How does trust influence this process? Second, for consistency and comparison purpose, we only look at the Yankee Bond market in this study. Although the Yankee Bond market is a large and liquid bond issuance market, it is not the 
only market for firms seeking international financing. In addition, a considerable amount of debt financing is conducted in the domestic market. These questions as to how the cost of debt and firm decisions are influenced by trust in such markets remain unexplored.

\section{Conclusion}

This paper examines the role of societal trust in affecting corporate debt financing. We document three important findings. First, firms in the country with higher level of societal trust are facing lower cost of debt. Higher trust could mitigate agency cost, lower monitoring and transaction cost. Therefore, investors are more willing to provide capital to the firm. Second, we find that trust and the associated informal governance institutions could largely substitute the effect of formal institutions in the process of debt financing. As a result, trust is more valuable for the country with weaker formal institutions. Lastly, we find that the financing cost of firms in a high trust country would experience a lower increase in the financial crisis compared to their peers in a low trust country, showing that societal trust is an important buffer for the firm when facing financial instability.

This paper reveals the unique value of trust to a firm. Default or distrust behavior may look profitable for some firms or even countries at a first glance. However, the breach of trust would lead to increased financing cost in the debt market. On the other hand, keeping the promise may be costly in the short run, but the associated lower financing cost would mitigate the loss in the long run. Our research also stresses the unique value of informal institutions in business activity. In a society where individuals are expected to fulfill their promises, strict regulation may not be needed and policy makers can utilize the flexibility of informal institutions to encourage economic growth. 
Overall, to our best knowledge, our paper is the first piece of research that links trust to corporate debt cost, which extends earlier studies examining the association between trust and other economic and financial activities and contributes to the finance literature by showing that trust may be economically and significantly related to corporate debt policy. 


\section{References}

Aghion, P., Van Reenen, J., Zingales, L., 2013. Innovation and institutional ownership. The American Economic Review 103, 277-304. https://doi.org/10.1257/aer.103.1.277

Ahern, K.R., Daminelli, D., Fracassi, C., 2015. Lost in translation? The effect of cultural values on mergers around the world. Journal of Financial Economics, NBER Conference on the Causes and Consequences of Corporate Culture 117, 165-189. https://doi.org/10.1016/j.jfineco.2012.08.006

Arrow, K.J., 1972. Gifts and exchanges. Philosophy and Public Affairs, 1, 343-362

Biddle, G.C., Hilary, G., Verdi, R.S., 2009. How does financial reporting quality relate to investment efficiency? Journal of Accounting and Economics 48, 112-131. https://doi.org/10.1016/j.jacceco.2009.09.001

Bottazzi, L., Da Rin, M., Hellmann, T., 2016. The importance of trust for investment: Evidence from venture capital. Review of Financial Studies 29, 2283-2318. https://doi.org/10.1093/rfs/hhw023

Boubakri, N., Ghouma, H., 2010. Control/ownership structure, creditor rights protection, and the cost of debt financing: International evidence. Journal of Banking \& Finance 34, 2481-2499. https://doi.org/10.1016/j.jbankfin.2010.04.006

Bris, A., Cabolis, C., 2008. The Value of Investor Protection: Firm Evidence from Cross-Border Mergers. Review of Financial Studies. 21, 605-648.

Bushee, B.J., 1998. The influence of institutional investors on myopic R\&D investment behavior. The Accounting Review 73, 305-333

Chami, R., Fullenkamp, C., 2002. Trust and efficiency. Journal of Banking \& Finance 26, 1785-1809. https://doi.org/10.1016/S0378-4266(02)00191-7

Chui, A.C.W., Lloyd, A.E., Kwok, C.C.Y., 2002. The determination of capital structure: Is national culture a missing piece to the puzzle? Journal of International Business Studies 33, 99-127. https://doi.org/10.1057/palgrave.jibs.8491007

Duarte, J., Siegel, S., Young, L., 2012. Trust and credit: The role of appearance in peer-to-peer lending. Review of Financial Studies 25, 2455-2484. https://doi.org/10.1093/rfs/hhs071

Dudley, E., Zhang, N., 2016. Trust and corporate cash holdings. Journal of Corporate Finance 41, 363-387. https://doi.org/10.1016/j.jcorpfin.2016.10.010

Fukuyama, F., 1995. Social capital and the global economy. Foreign Affairs 74, 89-103. https://doi.org/10.2307/20047302

Fukuyama, F., 1996. Trust: The Social Virtues and The Creation of Prosperity, 1st Free Press Paperback edition. ed. Free Press, New York, NY

García Lara, J.M., García Osma, B., Penalva, F., 2016. Accounting conservatism and firm investment efficiency. Journal of Accounting and Economics 61, 221-238. https://doi.org/10.1016/j.jacceco.2015.07.003

Ghaly, M., Dang, V.A., Stathopoulos, K., 2015. Institutional investment horizons and labor investment efficiency (SSRN Scholarly Paper No. ID 2606272). Social Science Research Network, Rochester, NY

Gilardi, F. (2010). Who learns from what in policy diffusion processes? American Journal of Political Science, 54(3), 650-666.

Gormley, T.A., Matsa, D.A., 2014. Common errors: How to (and not to) control for unobserved heterogeneity. Review of Financial Studies 27, 617-661. https://doi.org/10.1093/rfs/hht047

Guiso, L., Sapienza, P., Zingales, L., 2004. The role of social capital in financial development. American Economic Review 94, 526-556

Guiso, L., Sapienza, P., Zingales, L., 2008a. Trusting the stock market. The Journal of 
Finance 63, 2557-2600. https://doi.org/10.1111/j.1540-6261.2008.01408.x

Guiso, L., Sapienza, P., Zingales, L., 2008b. Trusting the Stock Market. The Journal of Finance 63, 2557-2600. https://doi.org/10.1111/j.1540-6261.2008.01408.x https://doi.org/10.1257/0002828041464498

Guiso, L., Sapienza, P., Zingales, L., 2009. Cultural biases in economic exchange? Quarterly Journal of Economics 124, 1095-1131. https://doi.org/10.1162/qjec.2009.124.3.1095

Hall, B.H., 1993. The stock market's valuation of R\&D investment during the 1980's. The American Economic Review 83, 259-264.

He, J., Tian, X., 2013. The dark side of analyst coverage: The case of innovation. Journal of Financial Economics 109, 856-878. https://doi.org/10.1016/j.jfineco.2013.04.001

Helmke, G., Levitsky, S., 2004. Informal institutions and comparative politics: A research agenda. Perspectives on Politics 2, 725-740.

Hilary, G., Huang, S., 2015. Trust and contracting (SSRN Scholarly Paper No. ID 2604974). Social Science Research Network, Rochester, NY.

Holmes, R.M., Miller, T., Hitt, M.A., Salmador, M.P., 2011. The interrelationships among informal institutions, formal institutions, and inward foreign direct investment. Journal of Management. https://doi.org/10.1177/0149206310393503

Hsu, P.-H., Tian, X., Xu, Y., 2014. Financial development and innovation: Cross-country evidence. Journal of Financial Economics 112, 116-135. https://doi.org/10.1016/j.jfineco.2013.12.002

Jackson, G., Deeg, R., 2008. Comparing capitalisms: Understanding institutional diversity and its implications for international business, Journal of International Business Studies, $39,540-561$

Knack, S., Keefer, P., 1997. Does social capital have an economic payoff? A cross-country investigation. Quarterly Journal of Economics 112, 1251-1288. https://doi.org/10.1162/003355300555475

Kaufmann, D., Kraay, A., 2008. Governance Indicators: Where Are We, Where Should We Be Going? The World Bank Research Observer Vol. 23, No. 1 (Spring, 2008), pp. 1-30

Kaufmann, D., Kraay, A., Mastruzzi, M., 2009. Governance Matters VIII: Aggregate and Individual Governance Indicators, 1996-2008. World Bank, Washington, DC

Lins, K.V., Servaes, H., Tamayo, A., 2017. Social capital, trust, and firm performance: The value of corporate social responsibility during the financial crisis. The Journal of Finance 72, 1785-1824. https://doi.org/10.1111/jofi.12505

Martynova, M., Renneboog, L., 2008. Spillover of corporate governance standards in cross-border mergers and acquisitions. Journal of Corporate Finance 14, 200-223.

Miller, D.P., Puthenpurackal, J.J., 2002. The costs, wealth effects, and determinants of international capital raising: Evidence from public Yankee Bonds. Journal of Financial Intermediation 11, 455-485. https://doi.org/10.1006/jfin.2002.0342

Myers, S.C., Majluf, N.S., 1984. Corporate financing and investment decisions when firms have information that investors do not have (Working Paper No. 1396). National Bureau of Economic Research.

Oikonomou, I., Brooks, C., Pavelin, S., 2014. The effects of corporate social performance on the cost of corporate debt and credit ratings. Financial Review 49, 49-75. https://doi.org/10.1111/fire.12025

Pevzner, M., Xie, F., Xin, X., 2015. When firms talk, do investors listen? The role of trust in stock market reactions to corporate earnings announcements. Journal of Financial Economics, NBER Conference on the Causes and Consequences of Corporate Culture 117, 190-223. https://doi.org/10.1016/j.jfineco.2013.08.004

Qi, Y., Roth, L., Wald, J.K., 2011. How legal environments affect the use of bond covenants. 
Journal of International Business Studies 42, 235-262.

https://doi.org/10.1057/jibs.2010.52

Redding, G., 2005. The thick description and comparison of societal systems of capitalism.

Journal of International Business Studies, 36, 123-155

Reed, M.I., 1996. Expert power and control in late modernity: An empirical review and theoretical synthesis. Organization Studies

Servaes, H., Tamayo, A., 2017. The role of social capital in corporations: a review. Oxford Review of Economic Policy 33, 201-220. https://doi.org/10.1093/oxrep/grx026

Stiglitz, J., 2008. The financial crisis is the fruit of dishonesty on the part of financial institutions [WWW document]. The Guardian, September 15. http://www.theguardian.com/commentisfree/2008/sep/16/economics. wallstreet (accessed 2.21.18).

Tian, X., Wang, T.Y., 2014. Tolerance for failure and corporate innovation. Review of Financial Studies 27, 211-255. https://doi.org/10.1093/rfs/hhr130

Tobin, J., 1958. Liquidity preference as behavior towards risk. The Review of Economic Studies, 25, 65-86

Williamson, O.E., 1993. Calculativeness, trust, and economic organization. Journal of Law \& Economics 36, 453-486.

Witt, M.A., Redding, G., 2009. Culture, meaning, and institutions: Executive rationale in Germany and Japan. Journal of International Business Studies 40, 859-885. https://doi.org/10.1057/jibs.2008.81

Zak, P.J., Knack, S., 2001. Trust and growth. The Economic Journal 111, 295-321. https://doi.org/10.1111/1468-0297.00609

Zilber, T.B., 2006. The work of the symbolic in institutional processes: Translations of rational myths in Israeli high tech. Academy of Management Journal 49, 281-303. https://doi.org/10.5465/AMJ.2006.20786073 


\begin{tabular}{|c|c|c|}
\hline \multicolumn{3}{|c|}{ Appendix A: Variables Description and Data Source } \\
\hline Variable & Description & Data Source \\
\hline \multicolumn{3}{|c|}{ Country-Level Variables: } \\
\hline Trust & $\begin{array}{l}\text { This captures trust level, calculated based on } \\
\text { responses to the WVS and EVS question: } \\
\text { "Generally speaking, would you say that most } \\
\text { people can be trusted or that you need to be } \\
\text { very careful in dealing with people?" The } \\
\text { value of trust is defined as the ratio of people } \\
\text { who responded that most people can be } \\
\text { trusted. We fill in the missing values following } \\
\text { the most recent surveys for the years between } \\
\text { the two adjacent surveys. }\end{array}$ & $\begin{array}{l}\text { World Value } \\
\text { Survey and } \\
\text { European } \\
\text { Value Survey }\end{array}$ \\
\hline Country & This captures country specific level of investor & World Bank \\
\hline Governance & protection. It is the sum of government & Worldwide \\
\hline $\begin{array}{l}\text { Indicator } \\
\text { (CGIndicator) }\end{array}$ & $\begin{array}{l}\text { effectiveness, regulatory quality, control of } \\
\text { corruption, political stability, rule of law, and } \\
\text { voice and accountability as described in } \\
\text { Kaufmann et al. (2009) at } \\
\text { http://data.worldbank.org/ } \\
\text { data-catalog/worldwide-governance-indicators. }\end{array}$ & $\begin{array}{l}\text { Governance } \\
\text { Indicator }\end{array}$ \\
\hline $\begin{array}{l}\text { Government } \\
\text { Effectiveness (GE) }\end{array}$ & $\begin{array}{l}\text { This captures perceptions of the quality of } \\
\text { public services, the quality of the civil service } \\
\text { and the degree of its dependence from political } \\
\text { pressures, the quality of policy formulation } \\
\text { and implementation, and the credibility of the } \\
\text { government's commitment to such policies. }\end{array}$ & $\begin{array}{l}\text { World Bank } \\
\text { Worldwide } \\
\text { Governance } \\
\text { Indicator }\end{array}$ \\
\hline $\begin{array}{l}\text { Regulatory Quality } \\
\text { (RE) } \\
\text { Control of } \\
\text { Corruption (CC) }\end{array}$ & $\begin{array}{l}\text { This captures perceptions of the ability of the } \\
\text { government to formulate and implement sound } \\
\text { policies and regulation that permit and } \\
\text { promote private sector development. } \\
\text { This captures perceptions of the extent to } \\
\text { which public power is exercised for private } \\
\text { gain. }\end{array}$ & $\begin{array}{l}\text { World Bank } \\
\text { Worldwide } \\
\text { Governance } \\
\text { Indicator } \\
\text { World Bank } \\
\text { Worldwide } \\
\text { Governance } \\
\text { Indicator }\end{array}$ \\
\hline
\end{tabular}


Political Stability

(PS)

Rule of Law (RL)

Voice and

Accountability (VA)

GDP Growth

(GDPgrowth)

Inflation

Debt Market Size

(DebtMkt)

Bond-Level Variables:

Spread

Issue Size (Lisize)

Maturity

Firm-Level Variables:

Firm Size (Asset)

Performance (ROI)

Leverage

Risk

FCrisis
This captures the level of political stability and absence of violence or terrorism.

This captures perceptions of the extent to which individuals and agents have confidence in and abide by the society, and in particular the quality of contract enforcement.

This captures perceptions of the extent to which a country's citizens are able to voice their opinions and participate in selecting their government.

Average annual growth of GDP.

Annual percentage changes of each country's Consumer Price Index (CPI). The ratio of total debts per year over this country's GDP.

The difference between the yield to maturity on the bond issue and the yield to maturity on a US Treasury Bond of similar maturity. The natural logarithm of the size (offering amount) of the issue in million US \$. The natural logarithm of the years to maturity.

The natural logarithm of the annual total assets of the firm in million US \$.

The return on investment of each firm.

The ratio of total debts to total assets of each firm.

The firm's operational risk measured by the standard deviation of return on assets (ROA) for the year-4 to year, more specifically, Risk is the standard deviation of ROA for year-4, year-3, year-2, year-1 and year. A dummy variable indicating the recent financial crisis. FCrisis is equal to one if the year is between 2007 and 2009, and zero otherwise.
World Bank

Worldwide

Governance

Indicator

World Bank

Worldwide

Governance

Indicator

World Bank

Worldwide

Governance

Indicator

World Bank

World Bank

World Bank

DataStream

DataStream

DataStream

Compustat

Compustat

Compustat

Compustat 


\begin{tabular}{ll}
\hline Appendix B: S\&P Credit Ratings Transformations & \\
\hline S\&P initial ratings & Transformation \\
AAA & 7 \\
AA+, AA, AA- & 6 \\
A+, A, A- & 5 \\
BBB+, BBB, BBB- & 4 \\
BB+, BB, BB- & 3 \\
B+, B, B- & 2 \\
CCC+, CCC, CCC-, CC, C, D & 1 \\
\hline
\end{tabular}




\section{Table 1}

Data Distribution

This table provides a description of the distribution of bond issues by year (reported in Panel A) and by country (reported in Panel B).

\begin{tabular}{|c|c|c|c|}
\hline \multicolumn{4}{|c|}{ Panel A: Issues by Year } \\
\hline Year & Number & Ratio \% & Cumulative \% \\
\hline 1996 & 7 & 0.11 & 0.11 \\
\hline 1997 & 5 & 0.08 & 0.20 \\
\hline 1998 & 3 & 0.05 & 0.25 \\
\hline 1999 & 14 & 0.23 & 0.48 \\
\hline 2000 & 18 & 0.30 & 0.77 \\
\hline 2001 & 7 & 0.11 & 0.89 \\
\hline 2002 & 13 & 0.21 & 1.10 \\
\hline 2003 & 18 & 0.30 & 1.39 \\
\hline 2004 & 14 & 0.23 & 1.62 \\
\hline 2005 & 30 & 0.49 & 2.12 \\
\hline 2006 & 98 & 1.61 & 3.72 \\
\hline 2007 & 102 & 1.67 & 5.40 \\
\hline 2008 & 1,049 & 17.20 & 22.60 \\
\hline 2009 & 981 & 16.09 & 38.68 \\
\hline 2010 & 1,740 & 28.53 & 67.22 \\
\hline 2011 & 764 & 12.53 & 79.75 \\
\hline 2012 & 605 & 9.92 & 89.67 \\
\hline 2013 & 308 & 5.05 & 94.72 \\
\hline 2014 & 186 & 3.05 & 97.77 \\
\hline 2015 & 136 & 2.23 & 100.00 \\
\hline Total & 6,098 & & \\
\hline \multicolumn{4}{|c|}{ Panel B: Issues by Country } \\
\hline Country & Number & Ratio \% & Cumulative \% \\
\hline Argentina & 5 & 0.08 & 0.08 \\
\hline Australia & 84 & 1.38 & 1.46 \\
\hline Belgium & 2 & 0.03 & 1.49 \\
\hline Brazil & 2 & 0.03 & 1.53 \\
\hline Canada & 20 & 0.33 & 1.85 \\
\hline Denmark & 3 & 0.05 & 1.90 \\
\hline Finland & 3 & 0.05 & 1.95 \\
\hline France & 13 & 0.21 & 2.16 \\
\hline Germany & 358 & 5.87 & 8.04 \\
\hline UK & 4,975 & 81.58 & 89.62 \\
\hline Greece & 4 & 0.07 & 89.69 \\
\hline India & 1 & 0.02 & 89.70 \\
\hline Ireland & 10 & 0.16 & 89.87 \\
\hline Japan & 13 & 0.21 & 90.08 \\
\hline Luxembourg & 18 & 0.30 & 90.37 \\
\hline Malaysia & 1 & 0.02 & 90.39 \\
\hline Mexico & 28 & 0.46 & 90.85 \\
\hline Netherlands & 137 & 2.25 & 93.10 \\
\hline Norway & 124 & 2.03 & 95.13 \\
\hline Singapore & 4 & 0.07 & 95.20 \\
\hline Sweden & 39 & 0.64 & 95.83 \\
\hline Switzerland & 254 & 4.17 & 100.00 \\
\hline Total & 6,098 & & \\
\hline
\end{tabular}




\section{Table 2}

\section{Summary Statistics}

This table reports the summary statistics of trust, country governance indicators, country-level controls, and bond spreads from 1996 to 2015.

\section{Panel A: Trust and Country Governance Level}

This panel reports the average level of trust and six dimensions of the country-level governance indicator across the world.

\begin{tabular}{llllllll}
\hline Country & Trust & $\begin{array}{l}\text { Government } \\
\text { Effectiveness }\end{array}$ & $\begin{array}{l}\text { Regulatory } \\
\text { Quality }\end{array}$ & $\begin{array}{l}\text { Control of } \\
\text { Corruption }\end{array}$ & $\begin{array}{l}\text { Political } \\
\text { Stability }\end{array}$ & $\begin{array}{l}\text { Rule of } \\
\text { Law }\end{array}$ & Accountability \\
Argentina & 0.18 & -0.02 & -0.38 & -0.39 & -0.11 & -0.51 & 0.28 \\
Australia & 0.46 & 1.72 & 1.62 & 1.94 & 1.02 & 1.75 & 1.45 \\
Belgium & 0.32 & 1.72 & 1.24 & 1.41 & 0.90 & 1.32 & 1.39 \\
Brazil & 0.07 & -0.07 & 0.19 & -0.05 & -0.12 & -0.27 & 0.35 \\
Canada & 0.41 & 1.87 & 1.60 & 2.05 & 1.02 & 1.73 & 1.51 \\
Denmark & 0.69 & 2.09 & 1.80 & 2.43 & 1.16 & 1.90 & 1.61 \\
Finland & 0.57 & 2.11 & 1.75 & 2.38 & 1.46 & 1.95 & 1.58 \\
France & 0.23 & 1.55 & 1.09 & 1.37 & 0.57 & 1.41 & 1.24 \\
Germany & 0.36 & 1.68 & 1.49 & 1.87 & 0.97 & 1.65 & 1.37 \\
UK & 0.32 & 1.73 & 1.80 & 1.91 & 0.55 & 1.68 & 1.33 \\
Greece & 0.20 & 0.64 & 0.74 & 0.31 & 0.33 & 0.72 & 0.92 \\
India & 0.32 & -0.08 & -0.35 & -0.42 & -1.14 & 0.10 & 0.38 \\
Ireland & 0.38 & 1.59 & 1.69 & 1.59 & 1.20 & 1.63 & 1.39 \\
Japan & 0.38 & 1.33 & 0.96 & 1.28 & 1.02 & 1.31 & 1.00 \\
Luxembourg & 0.27 & 1.83 & 1.73 & 2.00 & 1.40 & 1.79 & 1.53 \\
Malaysia & 0.09 & 1.02 & 0.56 & 0.31 & 0.18 & 0.49 & -0.35 \\
Mexico & 0.18 & 0.21 & 0.36 & -0.34 & -0.57 & -0.54 & 0.11 \\
Netherlands & 0.57 & 1.91 & 1.81 & 2.16 & 1.17 & 1.76 & 1.59 \\
Norway & 0.70 & 1.92 & 1.41 & 2.16 & 1.30 & 1.92 & 1.61 \\
Singapore & 0.21 & 2.15 & 1.98 & 2.23 & 1.11 & 1.56 & -0.03 \\
Sweden & 0.63 & 1.97 & 1.57 & 2.27 & 1.25 & 1.87 & 1.60 \\
Switzerland & 0.44 & 1.98 & 1.66 & 2.14 & 1.32 & 1.87 & 1.54 \\
\hline & & & & & & & \\
\hline
\end{tabular}




\section{Panel B: CGindicator, Country-Level Controls, and Bond Spread}

This panel reports the average level of the CGindicator (the aggregate of the six governance dimensions in Panel A), country-level controls, both mean and median values of bond spread across the world.

\begin{tabular}{lllllll}
\hline Country & CGindicator & GDPgrowth & Inflation & DebtMkt & $\begin{array}{l}\text { Mean Bond } \\
\text { Spread }\end{array}$ & $\begin{array}{l}\text { Median Bond } \\
\text { Spread }\end{array}$ \\
Argentina & -1.13 & 2.91 & -1.39 & 58.57 & 5.45 & 5.16 \\
Australia & 9.51 & 3.30 & 0.23 & 19.70 & 0.93 & 0.94 \\
Belgium & 7.99 & 1.80 & -2.18 & 103.7 & 2.10 & 2.10 \\
Brazil & 0.02 & 2.99 & -0.01 & 64.26 & 5.35 & 5.35 \\
Canada & 9.79 & 2.55 & 0.29 & 81.28 & 9.61 & 9.71 \\
Denmark & 10.98 & 1.28 & 0.02 & 45.58 & 1.67 & 1.81 \\
Finland & 11.24 & 2.25 & 1.04 & 45.11 & 1.41 & 1.24 \\
France & 7.23 & 1.59 & 0.89 & 70.33 & 2.18 & 1.45 \\
Germany & 9.02 & 1.33 & 0.19 & 66.49 & 7.82 & 8.46 \\
UK & 9.00 & 2.10 & 0.02 & 52.79 & 9.41 & 9.78 \\
Greece & 3.66 & 0.91 & -0.01 & 121.30 & 4.58 & 4.53 \\
India & -1.51 & 6.89 & 0.03 & 73.49 & 1.31 & 1.31 \\
Ireland & 9.09 & 4.62 & -0.32 & 59.43 & 3.57 & 2.81 \\
Japan & 6.90 & 0.84 & 2.68 & 179.8 & 0.94 & 0.64 \\
Luxembourg & 10.27 & 3.77 & 0.28 & 12.03 & 3.93 & 3.85 \\
Malaysia & 2.22 & 4.90 & 0.25 & 42.71 & 2.31 & 2.31 \\
Mexico & -0.77 & 2.92 & -0.09 & 43.01 & 4.26 & 4.00 \\
Netherlands & 10.40 & 1.94 & 0.04 & 57.29 & 5.82 & 5.50 \\
Norway & 10.33 & 2.13 & 0.39 & 36.00 & 12.66 & 12.53 \\
Singapore & 8.99 & 5.55 & 4.37 & 92.11 & 1.66 & 1.85 \\
Sweden & 10.52 & 2.40 & -0.16 & 53.31 & 4.69 & 6.66 \\
Switzerland & 10.51 & 1.94 & 2.02 & 52.74 & 10.31 & 9.96 \\
\hline & & & & & & \\
\hline
\end{tabular}




\section{Table 3}

Descriptive Statistics of All Variables

This table presents the descriptive statistics (reported in Panel A) and Pearson correlation (reported in Panel B) of all variables.

\begin{tabular}{|c|c|c|c|c|c|c|c|c|}
\hline \multicolumn{9}{|c|}{ Panel A: Descriptive Statistics of Variables } \\
\hline Variable & Obs. & Mean & Std. dev. & Min & 0.25 & Median & 0.75 & Max \\
\hline Spread & 6,098 & 9.083 & 5.100 & 0.000 & 6.640 & 9.630 & 11.93 & 19.83 \\
\hline Trust & 6,098 & 0.393 & 0.078 & 0.065 & 0.392 & 0.392 & 0.392 & 0.750 \\
\hline CGindicator & 6,098 & 8.469 & 1.007 & -3.221 & 8.283 & 8.310 & 8.527 & 11.80 \\
\hline GDPgrowth & 6,098 & 0.625 & 2.327 & -10.89 & -0.627 & 1.509 & 1.915 & 26.28 \\
\hline Inflation & 6,098 & 0.169 & 0.818 & -25.25 & -0.371 & 0.365 & 0.517 & 16.37 \\
\hline DebtMkt & 6,098 & 68.84 & 16.89 & 7.091 & 50.27 & 75.74 & 81.32 & 249.10 \\
\hline Maturity & 6,098 & 0.813 & 0.834 & 0.000 & 0.000 & 0.693 & 0.693 & 4.615 \\
\hline Lisize & 6,098 & 7.700 & 1.796 & 4.317 & 6.908 & 7.601 & 8.294 & 14.22 \\
\hline Asset & 6,098 & 14.38 & 1.061 & 7.847 & 14.62 & 14.66 & 14.70 & 14.90 \\
\hline ROI & 6,098 & 1.546 & 2.432 & -10.42 & 0.623 & 1.814 & 1.940 & 12.71 \\
\hline Leverage & 6,098 & 34.21 & 11.45 & 14.38 & 27.15 & 34.50 & 39.23 & 88.61 \\
\hline Risk & 6,098 & 0.436 & 1.459 & 0.046 & 0.106 & 0.141 & 0.148 & 9.726 \\
\hline
\end{tabular}


Panel B: Pearson Correlation. Note: ***,**, and *indicate significance at the $1 \%, 5 \%$, and $10 \%$ level, respectively.

\begin{tabular}{|c|c|c|c|c|c|c|c|c|c|c|c|c|}
\hline Spread & $\begin{array}{l}\text { Spread } \\
1\end{array}$ & Trust & CGindicator & GDPgrowth & Inflation & DebtMkt & Maturity & Lisize & Asset & ROI & Leverage & Risk \\
\hline Trust & $-0.079 * * *$ & 1 & & & & & & & & & & \\
\hline CGindicator & -0.002 & $0.544 * * *$ & 1 & & & & & & & & & \\
\hline GDPgrowth & $-0.372 * * *$ & $0.057 * * *$ & $0.146 * * *$ & 1 & & & & & & & & \\
\hline Inflation & $0.040 * * *$ & $-0.151 * * *$ & $0.041 * * *$ & $0.264 * * *$ & 1 & & & & & & & \\
\hline DebtMkt & $-0.199 * * *$ & $-0.100 * * *$ & $-0.280 * * *$ & $0.270 * * *$ & $-0.101 * * *$ & 1 & & & & & & \\
\hline Maturity & $-0.749 * * *$ & $0.056 * * *$ & $-0.049 * * *$ & $0.246^{* * *}$ & $-0.048 * * *$ & $0.150 * * *$ & 1 & & & & & \\
\hline Lisize & $-0.178 * * *$ & 0.020 & $0.044 * * *$ & $0.023^{*}$ & $-0.032 * *$ & $-0.247 * * *$ & $0.191 * * *$ & 1 & & & & \\
\hline Asset & $0.163 * * *$ & $-0.437 * * *$ & $-0.031 * *$ & $-0.121 * * *$ & $0.170 * * *$ & $0.225 * * *$ & $-0.221 * * *$ & $-0.488 * * *$ & 1 & & & \\
\hline ROI & $0.048 * * *$ & $-0.450 * * *$ & $-0.302 * * *$ & $-0.118 * * *$ & $0.090 * * *$ & $-0.118 * * *$ & $-0.053 * * *$ & 0.020 & $0.151 * * *$ & 1 & & \\
\hline Leverage & -0.019 & $0.581 * * *$ & $0.115 * * *$ & $0.091 * * *$ & $-0.027 * *$ & $-0.061 * * *$ & $0.028 * *$ & -0.010 & $-0.559 * * *$ & $-0.136 * * *$ & 1 & \\
\hline Risk & 0.011 & $0.516^{* * *}$ & $0.153 * * *$ & $-0.027 * *$ & $-0.113 * * *$ & $-0.242 * * *$ & $0.067 * * *$ & $0.266 * * *$ & $-0.768 * * *$ & $-0.239 * * *$ & $0.615 * * *$ & 1 \\
\hline
\end{tabular}




\section{Table 4}

The Impact of Trust on the Cost of Debt Financing: Baseline Regression Estimates

This table reports the OLS regression of trust on the cost of debt financing from 1996 to 2015. Each column reports estimates from a single regression, with robust standard errors clustered at the firm level in parentheses. Columns (1)-(2) report the full sample. Columns (3)-(4) and (5)-(6) only include the firms with a number of debt issues no more than 50 and 20 each year. All regressions control for both year and industry effects, and Columns (1), (3), and (5) also control for country effects. Note: ***, **, and * indicate significance at the $1 \%, 5 \%$, and $10 \%$ level, respectively.

\begin{tabular}{|c|c|c|c|c|c|c|}
\hline & \multicolumn{2}{|c|}{ Full Sample } & \multicolumn{2}{|c|}{ Issues $<=50$} & \multicolumn{2}{|c|}{ Issues $<=20$} \\
\hline & (1) & (2) & (3) & (4) & $(5)$ & (6) \\
\hline \multirow[t]{2}{*}{ Trust } & $-9.835 * *$ & $-7.139 * * *$ & $-8.311 *$ & $-6.798 * *$ & $-9.692 * *$ & $-6.168 * *$ \\
\hline & $(4.923)$ & $(1.745)$ & $(4.265)$ & $(2.700)$ & $(4.088)$ & $(2.938)$ \\
\hline \multirow[t]{2}{*}{ CGindicator } & -0.403 & 0.101 & -0.169 & 0.040 & -0.017 & 0.072 \\
\hline & $(0.357)$ & $(0.086)$ & $(0.356)$ & $(0.101)$ & $(0.387)$ & $(0.107)$ \\
\hline \multirow[t]{2}{*}{ GDPgrowth } & $0.182 * * *$ & $0.150 *$ & $0.102 * *$ & 0.067 & $0.129 * *$ & $0.095^{*}$ \\
\hline & $(0.063)$ & $(0.076)$ & $(0.049)$ & $(0.064)$ & $(0.058)$ & $(0.051)$ \\
\hline \multirow[t]{2}{*}{ Inflation } & $0.215 * * *$ & $0.176 * * *$ & $0.175^{* *}$ & $0.155^{*}$ & 0.122 & 0.101 \\
\hline & $(0.079)$ & $(0.056)$ & $(0.086)$ & $(0.082)$ & $(0.084)$ & $(0.082)$ \\
\hline \multirow[t]{2}{*}{ DebtMkt } & 0.014 & 0.010 & $0.043 * * *$ & 0.010 & $0.046 * *$ & 0.007 \\
\hline & $(0.018)$ & $(0.009)$ & $(0.016)$ & $(0.011)$ & $(0.018)$ & $(0.010)$ \\
\hline \multirow[t]{2}{*}{ Maturity } & $-4.055 * * *$ & $-4.081 * * *$ & $-1.673 * * *$ & $-2.122 * * *$ & $-0.890 * *$ & $-1.195 * *$ \\
\hline & $(0.229)$ & $(0.209)$ & $(0.590)$ & $(0.516)$ & $(0.376)$ & $(0.469)$ \\
\hline \multirow[t]{2}{*}{ Lisize } & $-0.228 * * *$ & $-0.250 * * *$ & $-0.488 * * *$ & $-0.560 * * *$ & $-0.447 * *$ & $-0.584 * * *$ \\
\hline & $(0.035)$ & $(0.042)$ & $(0.160)$ & $(0.126)$ & $(0.206)$ & $(0.211)$ \\
\hline \multirow[t]{2}{*}{ Asset } & -0.284 & -0.033 & -0.279 & 0.243 & -0.292 & -0.011 \\
\hline & $(0.215)$ & $(0.246)$ & $(0.227)$ & $(0.286)$ & $(0.228)$ & (0.194) \\
\hline \multirow[t]{2}{*}{ ROI } & -0.031 & -0.044 & $-0.109 * * *$ & -0.057 & $-0.103 * * *$ & -0.033 \\
\hline & $(0.034)$ & $(0.034)$ & $(0.025)$ & $(0.054)$ & $(0.027)$ & $(0.063)$ \\
\hline \multirow[t]{2}{*}{ Leverage } & -0.012 & 0.019 & 0.005 & 0.029 & 0.005 & 0.036 \\
\hline & $.022)$ & $(0.012)$ & $(0.020)$ & $(0.018)$ & $(0.020)$ & $(0.022)$ \\
\hline \multirow[t]{2}{*}{ Risk } & $0.349 * * *$ & $0.252 * * *$ & 0.108 & $0.303 * * *$ & 0.072 & $0.232 * *$ \\
\hline & $(0.099)$ & $(0.080)$ & $(0.100)$ & $(0.089)$ & $(0.096)$ & $(0.108)$ \\
\hline \multirow[t]{2}{*}{ Constant } & $17.594 * * *$ & $15.591 * * *$ & $13.684 * * *$ & $12.816^{* * *}$ & $12.346^{* * *}$ & $12.841 * * *$ \\
\hline & $(2.226)$ & $(2.434)$ & $(2.573)$ & (3.695) & (2.889) & (3.837) \\
\hline Year Effects & Yes & Yes & Yes & Yes & Yes & Yes \\
\hline Industry Effects & Yes & Yes & Yes & Yes & Yes & Yes \\
\hline Country Effects & Yes & No & Yes & No & Yes & No \\
\hline Observations & 6,098 & 6,098 & 711 & 711 & 433 & 433 \\
\hline R-squared & 0.638 & 0.634 & 0.709 & 0.632 & 0.653 & 0.506 \\
\hline
\end{tabular}




\section{Table 5}

\section{Country Governance and the Effect of Trust on the Cost of Debt Financing}

This table reports the OLS regressions in which Trust is interacted with CGIndicator and its sub-components. In order to avoid any multicollinearity issues, we exclude CGindicator in Columns (2)-(7), and only include each of the six dimensions of country governance and its interaction with Trust in those columns. Each column reports estimates from a single regression by including the same controls as reported in previous tables. To conserve space, we do not present controls. All regressions control for year, industry, and country effects. Note: $* * *, * *$, and $*$ indicate significance at the $1 \%, 5 \%$, and $10 \%$ level, respectively.

\begin{tabular}{|c|c|c|c|c|c|c|c|}
\hline VARIABLES & CGIndicator & $\begin{array}{l}\text { Government } \\
\text { Effectiveness } \\
\text { (GE) } \\
(2)\end{array}$ & $\begin{array}{l}\text { Regulatory } \\
\text { Quality } \\
\text { (RQ) } \\
\text { (3) }\end{array}$ & $\begin{array}{l}\text { Control of } \\
\text { Corruption } \\
\text { (CC) } \\
\text { (4) }\end{array}$ & $\begin{array}{l}\text { Political } \\
\text { Stability } \\
\text { (PS) } \\
(5)\end{array}$ & $\begin{array}{l}\text { Rule of } \\
\text { Law } \\
(\mathrm{RL}) \\
(6)\end{array}$ & $\begin{array}{c}\text { Voice and } \\
\text { Accountability } \\
\text { (VA) } \\
\text { (7) }\end{array}$ \\
\hline Trust & $\begin{array}{c}-33.894 * * * * \\
(8.995)\end{array}$ & $\begin{array}{c}-31.077 * * * \\
(10.484)\end{array}$ & $\begin{array}{c}-19.922 * * \\
(9.702)\end{array}$ & $\begin{array}{c}-31.189 * * * * \\
(9.362)\end{array}$ & $\begin{array}{c}-16.672 * * * * \\
(4.876)\end{array}$ & $\begin{array}{l}-12.248 \\
(9.167)\end{array}$ & $\begin{array}{c}-36.215^{* * * *} \\
(7.390)\end{array}$ \\
\hline CGindicator & $\begin{array}{c}-1.624 * * * \\
(0.585)\end{array}$ & & & & & & \\
\hline Trust*CGindicator & $\begin{array}{c}2.731 * * * \\
(0.996)\end{array}$ & & & & & & \\
\hline GE & & $\begin{array}{c}-6.503 * * \\
(2.844)\end{array}$ & & & & & \\
\hline Trust*GE & & $\begin{array}{c}12.420^{* *} \\
(5.541)\end{array}$ & & & & & \\
\hline RQ & & & $\begin{array}{l}-3.765 \\
(3.235)\end{array}$ & & & & \\
\hline Trust*RQ & & & $\begin{array}{c}5.945 \\
(6.777)\end{array}$ & & & & \\
\hline $\mathrm{CC}$ & & & & $\begin{array}{c}-7.661 * * * \\
(2.285)\end{array}$ & & & \\
\hline Trust*CC & & & & $\begin{array}{c}12.653 * * * \\
(4.432)\end{array}$ & & & \\
\hline PS & & & & & $\begin{array}{c}-3.643 * * \\
(1.826)\end{array}$ & & \\
\hline Trust*PS & & & & & $\begin{array}{l}9.281 * * \\
(3.917)\end{array}$ & & \\
\hline RL & & & & & & $\begin{array}{l}-3.206 \\
(2.890)\end{array}$ & \\
\hline Trust*RL & & & & & & $\begin{array}{c}2.240 \\
(5.592)\end{array}$ & \\
\hline VA & & & & & & & $\begin{array}{c}-8.434 * * * \\
(2.777)\end{array}$ \\
\hline Trust*VA & & & & & & & $\begin{array}{c}20.799 * * * \\
(5.595)\end{array}$ \\
\hline Controls & Yes & Yes & Yes & Yes & Yes & Yes & Yes \\
\hline Fixed Effects & Yes & Yes & Yes & Yes & Yes & Yes & Yes \\
\hline Observations & 6,098 & 6,098 & 6,098 & 6,098 & 6,098 & 6,098 & 6,098 \\
\hline R-squared & 0.638 & 0.638 & 0.638 & 0.639 & 0.638 & 0.638 & 0.638 \\
\hline
\end{tabular}




\section{Table 6}

The Financial Crisis and the Effect of Trust on the Cost of Debt Financing

This table reports the OLS regressions in which Trust is interacted with a dummy variable FCrisis indicating the period of the recent financial crisis. FCrisis is equal to one if the year is between 2007 and 2009, and zero otherwise. Both regressions control year, industry effects, and Column (1) also controls for country effects. The estimate results are clustered at the firm level. Note: $* * *, * *$, and $*$ indicate significance at the $1 \%, 5 \%$, and $10 \%$ level, respectively.

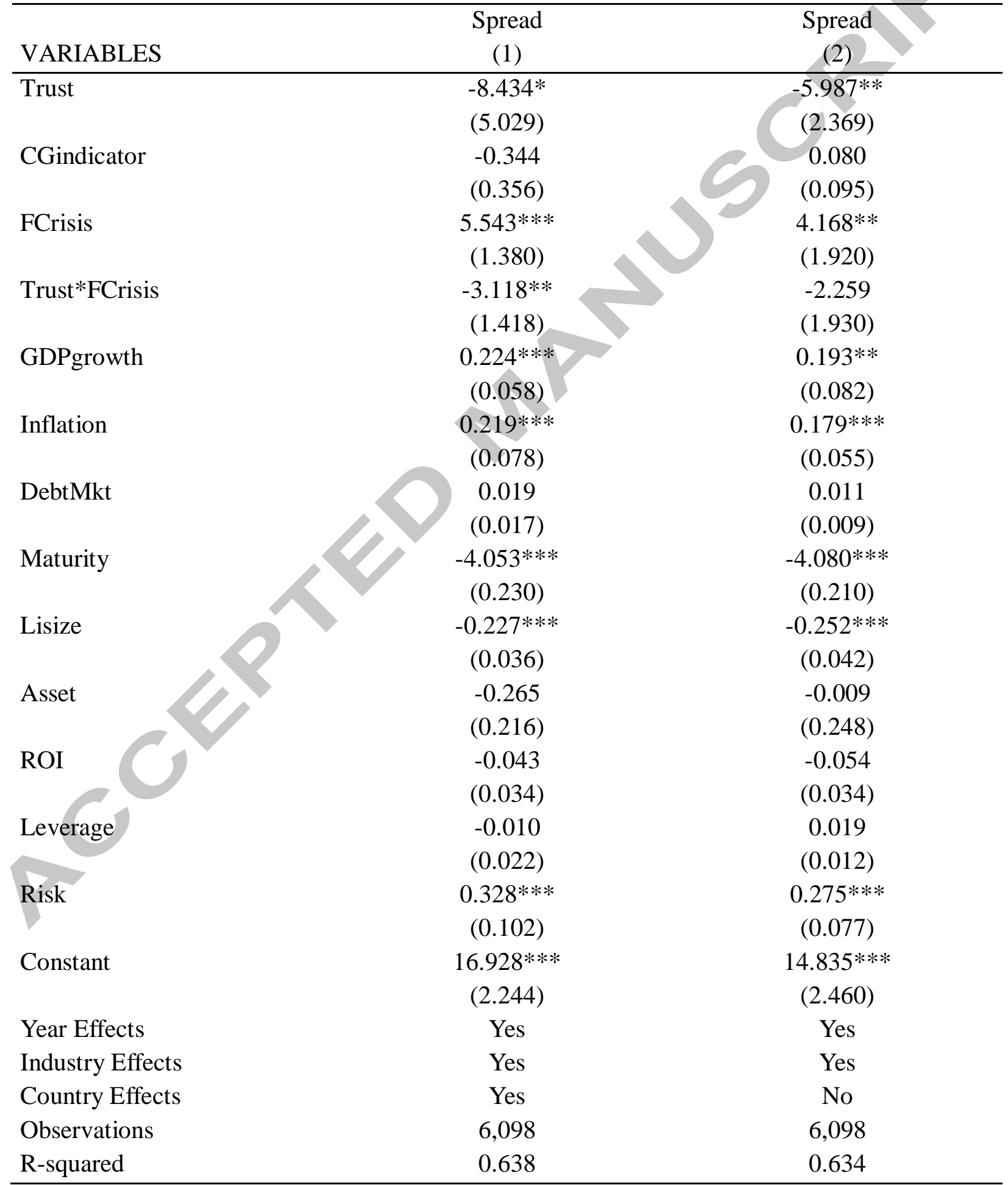




\section{Table 7}

Robustness Checks

This table performs a variety of robustness checks. The estimate results are clustered at the firm level. Note: $* * *, * *$, and $*$ indicate significance at the $1 \%, 5 \%$, and $10 \%$ level, respectively.

Panel A: Tobit Model. This panel re-runs estimations testing H1-H3 by employing the Tobit model proposed by James Tobin (Tobin, 1958).

\begin{tabular}{lccc}
\hline VARIABLES & $\mathrm{H} 1$ & $\mathrm{H} 2$ & $\mathrm{H} 3$ \\
\hline Trust & $(1)$ & $(2)$ & -4.999 \\
& $-10.417^{* *}$ & $-33.315^{* * *}$ & $(4.468)$ \\
CGindicator & $(5.100)$ & $(9.771)$ & $-0.612^{*}$ \\
& -0.410 & $-1.572^{* * *}$ & $(0.315)$ \\
Trust*CGindicator & $(0.360)$ & $(0.600)$ & \\
& & $2.599 * *$ & $5.181^{* * *}$ \\
FCrisis & & $(1.066)$ & $(1.771)$ \\
& & & $-7.916^{* *}$ \\
Trust*FCrisis & & & $(3.425)$ \\
Controls & & Yes & Yes \\
Fixed Effects & Yes & Year, Industry, and Country & 6,098 \\
Observations & \multirow{2}{*}{6,098} & 6,098 & 6.098 \\
\hline
\end{tabular}

Panel B: Reverse Causality. This panel re-runs estimations testing H1-H3 by employing the lagged value of trust, country governance indicator and the interaction terms.

\begin{tabular}{lccc}
\hline & $\mathrm{H} 1$ & $\mathrm{H} 2$ & $\mathrm{H} 3$ \\
VARIABLES & $(1)$ & $(2)$ & $(3)$ \\
\hline LagTrust & $-6.283^{*}$ & $-26.776^{* * *}$ & $-6.864^{* *}$ \\
& $(3.591)$ & $(7.280)$ & $(3.262)$ \\
LagCGindicator & -0.077 & $-1.198^{* *}$ & -0.348 \\
& $(0.353)$ & $(0.504)$ & $(0.299)$ \\
LagTrust*LagCGindicator & & $2.406^{* * *}$ & \\
& & $(0.823)$ & $5.083^{* * *}$ \\
FCrisis & & & $(1.861)$ \\
& & & $-8.988^{*}$ \\
LagTrust*FCrisis & & & $(4.535)$ \\
& & Yes & Yes \\
Controls & & Year, Industry, and Country & 6,098 \\
Fixed Effects & 6,098 & 6,098 & 0.638 \\
Observations & 0.638 & 0.638 & \\
R-squared & & & \\
\hline Par & & &
\end{tabular}

Panel C: Additional Robustness Checks. This panel re-runs estimations testing H1 by performing four additional robustness checks.

\begin{tabular}{|c|c|c|c|c|}
\hline VARIABLES & $\begin{array}{l}\text { Firm Fixed } \\
\text { Effects } \\
\text { (1) }\end{array}$ & $\begin{array}{l}\text { Higher Order Fixed } \\
\text { Effects } \\
(2)\end{array}$ & $\begin{array}{l}\text { Multicollinearity } \\
\text { Issue } \\
\text { (3) }\end{array}$ & $\begin{array}{l}\text { Credit } \\
\text { Ratings } \\
\text { (4) }\end{array}$ \\
\hline Trust & $\begin{array}{c}-3.426 * * * \\
(1.039)\end{array}$ & $\begin{array}{c}-15.337 * * * \\
(4.067)\end{array}$ & $\begin{array}{l}-9.287^{*} \\
(5.027)\end{array}$ & $\begin{array}{c}-11.253 * * \\
(4.348)\end{array}$ \\
\hline CGindicator & $\begin{array}{c}-0.801 * * * \\
(0.233)\end{array}$ & $\begin{array}{c}-0.893 * * \\
(0.436)\end{array}$ & & $\begin{array}{c}-1.079 * * * \\
(0.213)\end{array}$ \\
\hline S\&P Ratings & & & & $\begin{array}{c}-0.449 * * \\
(0.219)\end{array}$ \\
\hline Controls & Yes & Yes & Yes & Yes \\
\hline Fixed Effects & Firm & Higher Order & \multicolumn{2}{|c|}{ Year, Industry, and Country } \\
\hline Observations & 6,098 & 6,098 & 6,098 & 1,143 \\
\hline R-squared & 0.637 & 0.642 & 0.638 & 0.767 \\
\hline
\end{tabular}




\section{Highlights:}

1. We find that the level of societal trust in a country is negatively associated with the cost of debt financing.

2. This effect is stronger in countries where the formal governance institutions are weaker.

3. In addition, trust could mitigate the negative shock of financial crisis on the debt market.

4. Overall, trust is an important social capital that is related to the financing cost. 